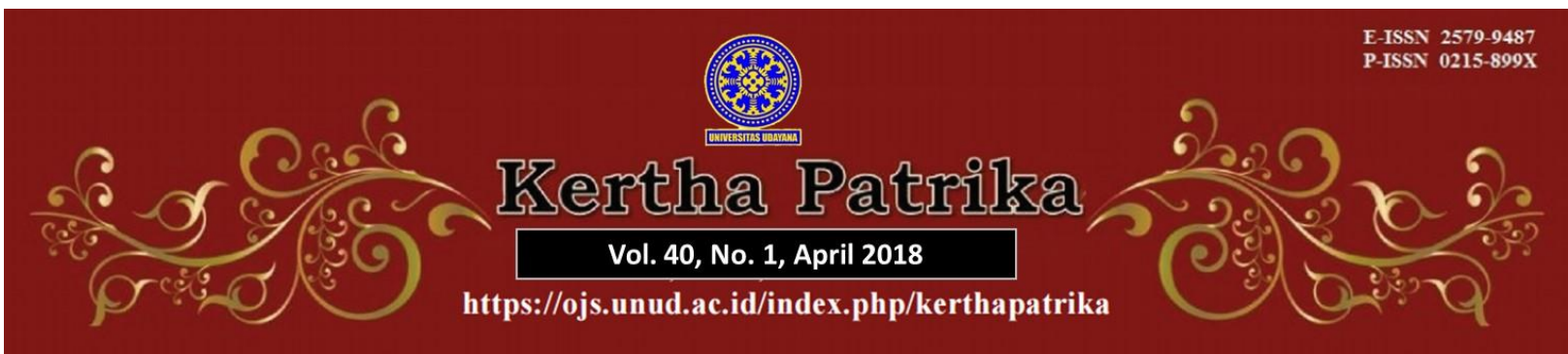

\title{
PENGALIHWUJUDAN KARYA SINEMATOGRAFI MENJADI VIDEO PARODI DENGAN TUJUAN KOMERSIAL PERSPEKTIF PERLINDUNGAN HAK CIPTA
}

Oleh :

Ari Mahartha ${ }^{1}$

Kantor Hukum RAH The House of Legal Experts

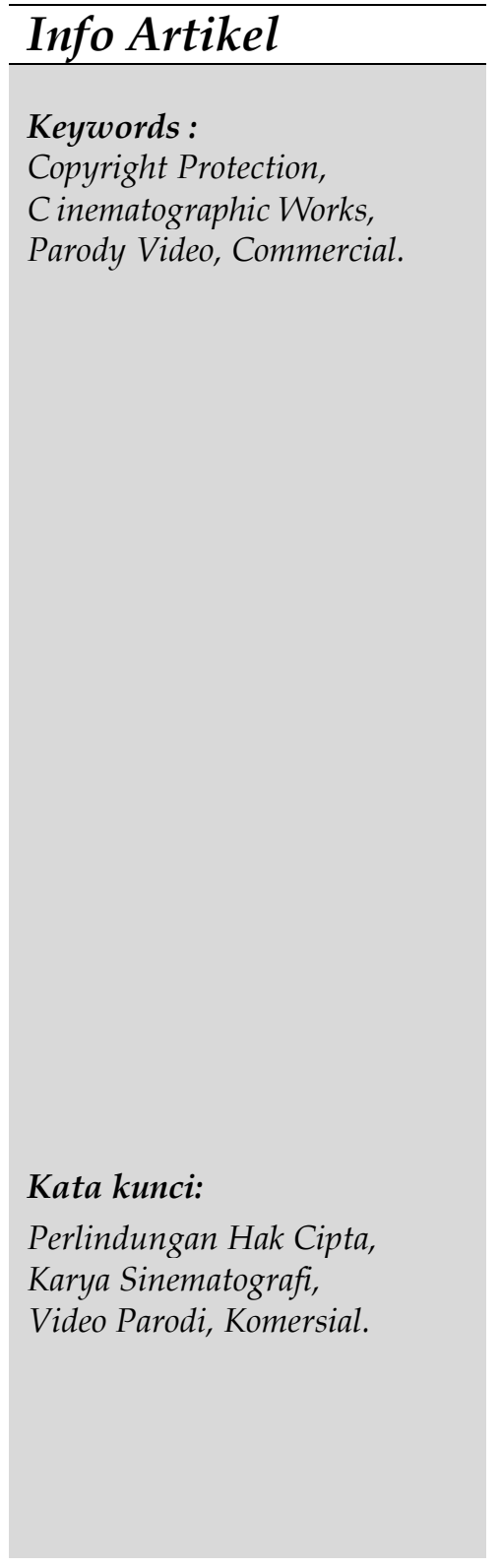

\begin{abstract}
YouTube, Instagram, and Facebook and other medias make people easy to share information including creative video parody. In general, parodies are made to criticism response or expression of work admiration. This paper aims to discuss the protection of parody that is adapted from other created works and the protection of copyright holders of cinematographic adapted into commercialized parody videos. This article is a normative legal research. The study shows that parody has already been legally protected through copyright both nationally and internationally. Parody which is adapted from cinematographic works for commercial purposes required to obtain copyright owner permission. A parodic video of the same form as adapted works in the form of cinematographic works, in the context of creation, has not received a clear protection because there is a vague norm formulation on Law Number 28 Year 2014 concerning Copyright. It is necessary to regulate clearly parody video, even though it is based on other creative works, actually, parody has unique contents that are the result of the creativity of a parody video creator. Clear arrangements are becoming increasingly important, especially when parodies are made for commercial purposes to avoid harming copyright owner protection of original work that is transformed to be a parody.
\end{abstract}

${ }^{1}$ Ari Mahartha adalah Asisten Lawyer di Kantor Hukum RAH The House of Legal Experts, Denpasar Bali. Korespondensi dengan penulis melalui email: ari.mahartha@gmail.com. 


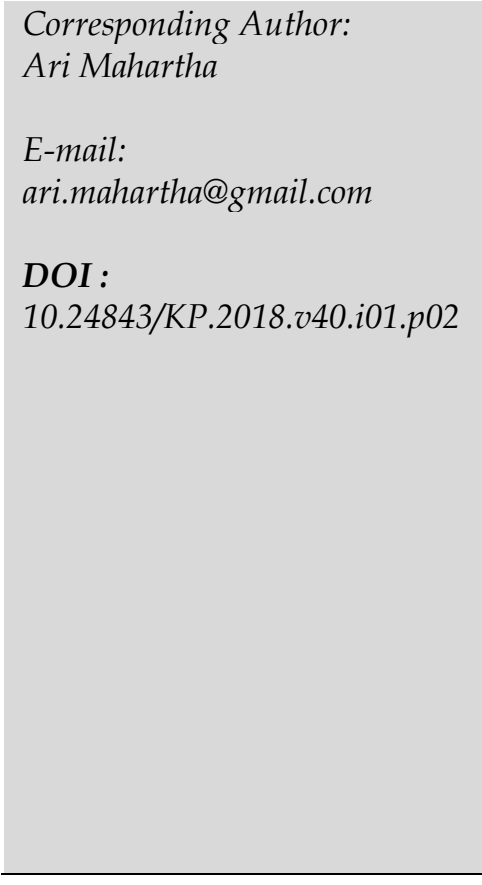

Corresponding Author:

E-mail:

ari.mahartha@gmail.com

DOI :

10.24843/KP.2018.v40.i01.p02

\section{Pendahuluan}

Perkembangan teknologi yang sangat pesat pada dunia maya dewasa ini memberi ruang tersendiri bagi orang-orang yang kreatif melahirkan karya cipta dalam berbagai ekspresi, termasuk salah satunya karya video Parodi. Dunia maya kini menjadi suatu ruang tanpa batas yang digunakan oleh masyarakat sebagai suatu wadah yang sangat mudah dijangkau untuk menyalurkan berbagai ekspresi yang tidak dapat tersalurkan di dunia nyata secara langsung maupun melalui media konvensional lainnya. Perkembangan dunia maya dengan askes internet yang semakin mudah, serta semakin berkembangnya platform-platform di dunia maya seperti Youtube, Instagram, Facebook dan lain sebagainya membuat seseorang selain dengan mudah dapat membagikan pengalaman atau ceritanya, seseorang juga dapat memanfaatkan media-media tersebut sebagai suatu sarana untuk mengumumkan karya ciptaanya yang merupakan hasil pemikiran kreatifnya secara pribadi agar dapat dinikmati oleh khalayak umum. Karya cipta mendapat perlindungan hukum hak cipta yang merupakan salah satu dari rezim hukum kekayaan intelektual. Konsep Hak Kekayaan Intelektual pada dasarnya dimaknai sebagai penghargaan dari kreativitas seseorang baik dalam bentuk penemuan-penemuan maupun hasil karya cipta dan seni. ${ }^{2}$ Dalam perkembangannya, karya cipta yang diumumkan secara luas melalui sebuah media sosial menjadi lebih cepat menjadi konsumsi masyarakat, serta dapat menjadikan penciptanya dikenal secara luas, termasuk karya Parodi.

Karya Parodi umumnya lahir sebagai suatu bentuk ungkapan kekaguman atau bahkan tidak jarang kritikan atas fenomena sosial yang sedang terjadi di masyarakat. Parodi yang menjadi terkenal setelah diunggah di media social salah satunya Parodi Arya Wiguna pada tahun 2013 yang diunggah melalui situs video sharing Youtube tahun 2013, awalnya karya-karya Parodi dibuat hanya sebagai ekspresi kebiasaan sehari-hari

2 Roisah, K. (2015). Konsep Hukum Hak Kekayaan Intelektual (HKI): Sejarah, Pengertian, Dan Filosofi Pengakuan HKI Dari Masa Ke Masa. Setara Press. Malang, h. 2. 
namun karena karyanya diminati oleh masyarakat pada akhirnya bisa menjadi pilihan profesi. Berkarya dan mendatangkan penghasilan melalui media sosial sangat peluang, terlebih setelah kecepatan akses internet berkembang pesat serta menurut data Global Web Index, Indonesia masuk ke dalam kategori negara yang paling aktif menggunakan media sosial. ${ }^{3}$ Selain fenomena social atau realitas sosial, keberadaan suatu karya yang dipublikasikan sebelumnya juga dapat menjadi suatu pemicu lahirnya karya ciptaan baru lainnya. Karya yang sudah ada dapat menginspirasi pihak lain untuk mengadakan suatu ciptaan baru dengan cara mengalihwujudkan karya asli tersebut kepada bentuk lainnya, termasuk mengalihwujudkannya karya sinematofrafi menjadi karya Parodi.

Pengalihwujudan karya sinematografi menjadi sebuah karya video Parodi ini banyak ditemukan pada platform online seperti Youtube dan Instagram yang memungkinkan penggunanya untuk mengunggah videonya secara gratis. Karya sinematografi yang dijadikan objek pengalihwujudan beragam jenisnya seperti video music dari penyanyipenyanyi ternama, karya sinematografi berupa film, tayangan-tayangan televisi, iklaniklan komersil dan lain sebagainya. Dalam proses pembuatan video parodi dari berbagai karya sinematografi tersebut, pihak lain memiliki kebebasan untuk mengekspresikan ide yang sama atau menggunakan kembali informasi yang diperoleh dari ciptaan atau karya yang dilindungi kedalam karya sesudahnya selama ide tersebut diekspresikan dengan cara yang berbeda. ${ }^{4}$ Namun kemudian karya ciptaan baru yang dihasilkan sebagai bentuk pengalihwujudan karya sinematografi berupa video parodi tersebut tidak jarang memperoleh reaksi yang tidak terduga dari masyarakat yang bahkan popularitasnya mampu mengalahkan karya ciptaan aslinya. Hal ini kemudian menjadi suatu persoalan ketika pembuat video parodi memperoleh keuntungan finansial dari beredarnya video yang dibuatnya yang bersinggungan dengan hak ekonomi dari pemilik karya sinematografi aslinya.

Berdasarkan latar belakang yang telah dipaparkan di atas, maka menjadi penting mengkaji secara mendalam isu hukum yang berkaitan dengan Bagaimana pengaturan hukum berkaitan dengan karya video parodi yang dibuat berdasarkan suatu karya ciptaan lainnya, serta Bagaimanakahn perlindungan hukum terhadap pemegang hak cipta atas karya sinematografi yang atas karyanya dibuat dan dialihwujudkan menjadi video parodi yang dikomersialisasikan?

Penelitian ini jika dibandingkan dengan studi-studi terdahulu memiliki kesamaan dari segi topik yaitu sama-sama mengkaji karya cipta pengalihwujudan, namun fokus kajiannya berbeda. Tulisan ini lebih menekankan pada perlindungan hukum bagi pemegang karya cipta sinematografi sebagai karya cipta awal yang dialihwujudkan menjadi karya video Parodi yang juga termasuk dalam kategori sinematografi untuk tujuan komersial yang mendatangkan manfaat ekonomi bagi pembuat video parodi. Dengan kata lain, pengalihwujudan dari karya sinematografi ke sinematografi video.

3Putri, A. A. S, (2016). "Pamer" Kreativitas di Media Sosial itu Perlu, asal..., https://entertainment.kompas.com/read/2016/04/29/081628110/.Pamer.Kreativitas.di.Med ia.Sosial.itu.Perlu.asal., diakses 28 Maret 2018.

${ }^{4}$ Dewi, A. A. M. S. (2017). Perlindungan Hukum Hak Cipta Terhadap Cover Version Lagu Di Youtube. Jurnal Magister Hukum Udayana (Udayana Master Law Journal), 6(4), h. 508-510. DOI: https:// doi.org/10.24843/JMHU.2017.v06.i04.p09. 
Pada umumnya pengalihwujudan bentuknya berbeda, misalnya dari karya buku menjadi karya film. Studi terdahulu dilakukan Anak Agung Mirah Satria Dewi pada tahun 2017, mengkaji tentang perlindungan hukum hak cipta terhadap Cover Version lagu di Youtube. Dalam hal ini, penekanannya pada karya cipta lagu yang dinyanyikan kembali (cover version) video untuk tujuan komersial yang diunggah melalui media Youtube. ${ }^{5}$ Desyanti Suka Asih K. Tus pada tahun 2014 juga melakukan studi tentang dengan pengalihwujudan karya cerita rakyat menjadi karya seni pertunjukan melalui media elektronik, studinya menekankan bahwa pada intinya perlindungan hak cipta diberikan dengan memperhatikan unsur keaslian. Kreteria asli tidak sama dengan baru. Keaslian berkaitan dengan unsur kretivitas yang khas. ${ }^{6}$

Tujuan dari penulisan ini adalah untuk mengelaborasi, mengidentifikasi dan menganalisis perlindungan hukum terhadap pemegang hak cipta atas karya cipta sinematografi yang dialihwujudkan untuk tujuan komersial berdasarkan UndangUndang No. 28 Tahun 2014 Tentang Hak Cipta. Dalam rangka mewujudkan tujuan penulisan, secara sistematis dalam tulisan ini disajikan substansi yang relevan dengan focus permasalahan. Pertama, disajikan tentang perlindungan hukum atas karya cipta baik secara nasional maupun internasional. Kedua, dielaborasi secara mendalam perlindungan karya cipta Parodi dalam kerangka hukum Hak Cipta. Ketiga, dikaji perlindungan hukum bagi pemegang hak cipta sinematografi yang dialihwujudkan menjadi Parodi dengan tujuan komersial.

\section{Metode Penelitian}

Penulisan karya ilmiah ini menggunakan jenis penelitian hukum normatif. Penelitian hukum normatif artinya penelitian yang bertitik berat terhadap bahan hukum berupa aturan atau norma hukum positif dan menjadi bahan acuan utama dalam penelitian. ${ }^{7}$ Sedangkan menurut Peter Machmud Marzuki, penelitian hukum adalah suatu proses untuk menemukan aturan hukum, prinsip-prinsip hukum, maupun doktrin-doktrin hukum guns menjawab isu hukum yang dihadapi. ${ }^{8}$ Oleh karena itu, penelitian hukum merupakan suatu penelitian di dalam kerangka know-how di dalam hukum. ${ }^{9}$ Pendekatan yang digunakan dalam penelitian ini adalah pendekatan perundangundangan (the statute approach) yang dilakukan dengan cara mengkaji UndangUndang No. 28 Tahun 2014 tentang Hak Cipta, serta pendekatan konsep (conceptual approach), yaitu mengkaji konsep pengalihwujudan maupun parodi. Adapun bahan hukum yang digunakan terdiri dari bahan hukum primer, bahan hukum sekunder, dan bahan hukum tersier, yang dianalisa secara kualitatif.

${ }^{5}$ Ibid.

6 Tus, D. S. A. K. (2014). Perlindungan Hukum terhadap Keaslian Cerita Rakyat. Jurnal Magister Hukum Udayana (Udayana Master Law Journal), 3(3), h. 472.

DOI: https://doi.org/10.24843/JMHU.2014.v03.i03.p09

7 Soekanto, S. \& Mamuji, S. (2001). Penelitian Hukum Normatif Suatu Tinjauan Singkat. Jakarta. Raja Grafindo Persada. h. 51.

8 Marzuki, P. M. (2009). Penelitian Hukum. Kencana Prenada Media Group. Cetakan ke-5. Jakarta, h. 35 .

9 Ibid., h. 15. 


\section{Hasil dan Pembahasan}

\subsection{Konsep dan Perlindungan Hukum Parodi Sebagai Karya Cipta}

Pemahaman mengenai apa sesungguhnya yang dimaksud dengan parodi dapat ditelusuri salah satunya dari encyclopedia. The Encyclopedia of Britannica mengemukakan bahwa parody, in literature, an imitation of the style and manner of a particular writer or school of writers. Parody is typically negative in intent: it calls attention to a writer's perceived weaknesses or a school's overused conventions and seeks to ridicule them. Parody can, however, serve a constructive purpose, or it can be an expression of admiration. It may also simply be a comic exercise. ${ }^{10}$ Kata Parody berasal dari bahasa Yunani parōidía, yaitu sebuah lagu yang dinyanyikan bersama dengan yang lain.

Dalam bidang sastra, konsep parodi dikenal sebagai tiruan gaya dan cara seseorang dalam hal karya seni yang biasanya mengedepankan pandangan negatif dari seseorang tersebut dengan usaha untuk mengejek karya tersebut, namun terkadang dapat juga berupa ekspresi kekaguman seseorang terhadap suatu karya. Kamus Besar Bahasa Indonesia mendefinisikan parodi sebagai suatu karya sastra atau seni yang dengan sengaja menirukan gaya, kata penulis, atau pencipta lain dengan maksud mencari efek kejenakaan. ${ }^{11}$

Parodi sebagai suatu karya kreatif manusia dalam konteks hukum kekayaan intelektual mendapat perlindungan melalui rezim hak cipta. Sebagaimana diketahui karya cipta yang mendapat perlindungan hak cipta adalah karya di bidang seni, sastra dan ilmu pengetahuan. Parodi dapat dikategorisasikan di bidang karya seni, oleh karenanya relevan rezim hukum hak cipta melindunginya. Hak Cipta menganut perlindungan secara otomatis atau menganut sistem dekralatif. Karya cipta yang diumumkan kepada khalayak umum, dapat secara serta merta memperoleh perlindungan hak cipta. Perlindungan secara otomatis pada hak cipta ini didasari pada Konvensi Berne. Prinsip automatically protection dianut oleh Berne Convention, berdasarkan konsep ini, mendaftarkan suatu ciptaan bukanlah merupakan suatu kewajiban yang mutlak harus dilakukan, melainkan menjadi suatu hal yang sifatnya fakultatif. ${ }^{12}$ Suatu karya mendapat perlindungan hak cipta menurut Miller dan Davis berdasarkan kreteria keaslian (originality). Unsur keaslian dalam hak cipta manakala ciptaan tersebut merupakan suatu hasil kreatifitas yang menunjukkan kekhasan dan bersifat pribadi. ${ }^{13}$ Karya cipta yang lahir dari kreativitas manusia, akal, budi, dan kemampuan intelektual yang tinggi tidak dapat dilepaskan dari pengorbanan waktu, tenaga serta usaha yang maksimal dari individu yang menghasilkan karya tersebut. Oleh karenanya, sudah sepantasnya mendapat perlindungan hukum dalam bentuk hak eksklusif bagi penciptanya dan mendapat pengakuan dari negara. Hak Cipta selain diatur dalam Berne Convention, secara internasional juga diatur melalui TRIPs

10 The Encyclopedia of Britannica, https://www.britannica.com/art/parodi-literature, diakses pada tanggal 28 Maret 2018

${ }^{11}$ Kamus Besar Bahasa Indonesia (KBBI) - Kamus versi online/daring (dalam jaringan), https:/ / kbbi.web.id/parodi, diakses pada tanggal 28 Maret 2018

${ }^{12}$ Supasti, N. K. (2014). Relevansi Hak Kekayaan Intelektual Dengan Hak Asasi Manusia Generasi Kedua. Jurnal Dinamika Hukum, 14(3), h. 525. DOI: http:/ /dx.doi.org/10.20884/1.jdh.20

${ }^{13}$ Ibid. 
Agreement yang mewajibkan negara-negara anggotanya termasuk Indonesia untuk mengharmonisasikan standar perlindungan hak kekayaan intelektual termasuk hak cipta sesuai standar TRIPs Agreement. ${ }^{14}$ Sudah menjadi kewajiban bagi negara untuk menghormati, mengakui serta memberi perlindungan hukum atas karya kreatif yang lahir dari kemampuan intelektual sebagai refleksi kepribadian individu yang dinamis. 15

Parodi sebagai suatu karya kreativitas intelektual manusia di Indonesia mendapat perlindungan berdasarkan ketentuan Pasal 40 huruf n Undang-Undang No. 28 Tahun 2014 (UU HC). Parodi dalam UU HC dikenal dengan sebutan "transformasi" dan "adaptasi". Berdasarkan Penjelasan Pasal 40 huruf n UU HC diatur bahwa yang dimaksud dengan adaptasi adalah mengalihwujudkan suatu ciptaan menjadi bentuk lain. Sebagai contoh dari buku menjadi film. Sementara itu, yang dimaksud dengan "karya lain dari hasil transformasi" adalah merubah format ciptaan menjadi format bentuk lain. Sebagai contoh musik pop menjadi musik dangdut.

Parodi di dunia internasional dikenal dengan istilah derivative work. Di Amerika, berdasarkan 17 USCS $\S 101$, a derivative work is a work based upon one or more preexisting works such as a translation, musical arrangement, dramatization, fictionalization, motion picture version, sound recording, art reproduction, abridgment, condensation, or any other form in which a work may be recast, transformed or adapted. A work consisting of editorial revisions, annotations, elaborations, or other modifications which, as a whole, represent an original work of authorship, is a derivative work. Berdasarkan definisi karya turunan menurut UndangUndang Hak Cipta, dapat diketahui bahwa karya turunan di Amerika adalah sebuah karya yang didasarkan pada satu atau lebih karya yang sudah ada sebelumnya. Karya turunan tidak melanggar jika dibuat berdasarkan persetujuan dari pemilik hak cipta dari karya yang mendasarinya, atau jika didasarkan pada karya di domain publik. ${ }^{16}$ Lebih jauh the Berne Convention sebagai Konvensi tertua yang mengatur Hak Cipta mengatur tentang derivative works melalui Article 2 (3) Berne Convention. Secara lebih detail Article 2(3) defines derivative works as translations, adaptations, arrangements of music and other alterations of a literary or artistic work, which shall be protected as original works without prejudice to the copyright in the original work. Berdasarkan Konvensi Berne tersebut dapat dipahami bahwa karya turunan sebagai terjemahan, adaptasi, pengaturan music dan perubahan lain dari karya sastra atau karya seni, harus dilindungi sebagai karya asli tanpa mengurangi hak cipta dalam karya aslinya.

${ }^{14}$ Dharmawan, N. K. S. (2017). Protecting Traditional Balinese Weaving Trough Copyright Law: Is It Appropriate? Diponegoro Law Review, 2(1), h. 16.

${ }^{15}$ Dharmawan, N. K. S. (2011). Hak Kekayaan Intelektual Dan Harmonisasi Hukum Global (Rekonstruksi Pemikiran Terhadap Perlindungan Program Komputer). Badan Penerbit Universitas Diponegoro, Semarang, h. 43.

16US Legal, Derivative Work Law and Legal Definition, https://definitions.uslegal.com/d/derivative-work/. 


\subsection{Perlindungan Karya Video Parodi yang Dialihwujudkan Dari Karya Ciptaan Lainnya Berdasarkan Undang-Undang Nomor 28 Tahun 2014 Tentang Hak Cipta}

Karya kreativitas video parodi dalam praktiknya kerap kali dibuat oleh seseorang dengan cara mengambil suatu karya sinematografi lainnya yang telah lebih dahulu dipopulerkan oleh orang lain. Video parodi ini biasanya dibuat sebagai respon seseorang terhadap suatu karya yang dapat dimaksudkan untuk suatu kritikan maupun ekspresi kekaguman seseorang terhadap karya tersebut. Dalam konteks ketentuan hak cipta, penciptaan karya seperti itu disebut sebagai bentuk pengalihwujudan atau karya cipta turunan yang juga dikenal dengan istilah derivative work. Karya pengalihwujudan dalam perkembangannya sekarang ini acapkali dilakukan terhadap karya cipta sinematografi.

Berdasarkan Penjelasan Pasal 40 Ayat (1) huruf m. Undang-Undang No. 28 Tahun 2014 Tentang Hak Cipta (UU HC) karya sinematografi diberikan difinisi sebagai ciptaan yang berupa gambar bergerak (moving images) antara lain film dokumenter, film iklan, reportase atau film cerita yang dibuat dengan skenario, dan film kartun. Karya sinematografi dapat dibuat dalam pita seluloid, pita video, piringan video, cakram optik dan/atau media lain yang memungkinkan untuk dipertunjukkan di bioskop, layar lebar, televisi, atau media lainnya. Sinematografi merupakan salah satu contoh bentuk audiovisual. Perlindungan karya sinematografi dalam UU HC tercantum dalam Pasal 40 Ayat (1) huruf m. Berdasarkan ketentuan tersebut, dapat dicermati bahwa karya sinematografi yang dibuat sejak awal oleh penciptanya termasuk yang dibuat dalam bentuk video akan mendapat perlindungan hak cipta.

Berkaitan dengan karya cipta sinematografi yang dibuat dalam bentuk video seperti tersebut di atas, yang kemudian dialihwujudkan menjadi parodi di yang juga dalam bentuk video oleh pihak lain, jika ditinjau semata-mata dari segi karya sebagai hasil akhir dari video parodi, memang menghasilkan karya video parodi yang termasuk dalam kategori sebagai karya sinematografi. Namun jika ditinjau secara keseluruhan dari proses bagaimana video parodi itu diciptakan maka unsur orisinalitas tidak terpenuhi mengingat video parodi ini dibuat berdasarkan atau terinspirasi dari suatu karya ciptaan sinematografi lainnya. Video parodi dibuat semata-mata dengan membuat ulang suatu karya sinematografi yang diselipkan muatan-muatan humor di dalamnya.

UU HC mengenal dan mengatur karya ciptaan lainnya yang memperoleh perlindungan hak cipta yang memiliki kemiripan dengan proses penciptaan video parodi yaitu karya lain dari hasil transformasi, sebagaimana diatur dalam Pasal 40 ayat (1) huruf n, yang dalam Penjelasannya didefinisikan sebagai "merubah format Ciptaan menjadi format bentuk lain." Sebagai contoh, musik pop menjadi musik dangdut. Mengenai perbuatan ini, UU HC belum memberikan pembatasan yang jelas terkait sejauhmana suatu karya ciptaan khususnya dalam hal ini karya sinematografi dapat ditransformasikan mengingat format ciptaan antara video parodi dan karya cipta asalnya adalah dalam suatu format yang sama yaitu gambar bergerak (moving images), sedangkan dalam Penjelasan tersebut disebutkan adanya perbedaan genre music yang tentu tidak dapat diaplikasikan secara serupa dengan jenis karya ciptaan lainnya. Misalnya film, apakah yang dimaksud transformasi adalah mengubah genre film 
drama menjadi film horror? Pertanyaan inilah yang belum dapat dijelaskan secara konkrit dalam UU HC. Sehingga dalam hal ini karya ciptaan video parodi, dengan rumusan norma yang kabur pada UU HC belum dapat memberikan perlindungan yang jelas terhadap video parodi tersebut. Perlindungan terhadap ciptaan video parodi diperlukan karena suatu ciptaan video parodi walaupun dibuat berdasarkan karya ciptaan lainnya, tetapi memiliki muatan-muatan khas yang merupakan hasil olah pemikiran dari pencipta video parodi. Tentunya perlindungan yang dimaksud harus diiringi dengan persyaratan yang jelas dalam pengaturannya, seperti harus memperoleh izin dari pemilik karya asli dan lain sebagainya. Sehingga dalam hal ini pencipta video parodi juga dapat memiliki hak atas karya ciptaannya.

Sebagai suatu perbandingan, di Amerika Serikat dikenal ciptaan yang disebut dengan derivative works yang dihasilkan dari berbagai tindakan alih wujud. Amerika Serikat tidak sekedar mengenal perubahan bentuk saja sebagai pengertian pengalihwujudan tetapi juga berbagai tindakan lain yang dianggap dapat menghasilka karya derivative. Agar dapat memenuhi syarat sebagai pengalihwujudan, karya tersebut harus melalui proses mengubah (mentransformasi), mengadaptasi, atau memodifikasi karya yang ada. ${ }^{17}$ Derivative works tersebut kemudian di Amerika Serikat dibatasi oleh pembatasan fair use yaitu dalam proses pembuatannya melalui cara-cara yang tidak melanggar hukum. Amerika Serikat juga memperbolehkan penggunaan karya cipta asal secara menyuluruh untuk parodi.. Parodi adalah pengecualian di dalam fair use, meskipun menggunakan keseluruhan karya cipta hingga ke hal yang paling inti atau mendasar dari suatu karya cipta diperbolehkan dalam hukum. Terdapat beberapa faktor parodi digolongkan sebagai fair use: parodi dianggap sebagai salah satu bentuk pemberian kritik terhadap hal-hal yang dianggap aneh atau janggal pada suatu karya cipta. Kedua, parodi dapat meningkatkan minat masyarakat terhadap karya asal. Ketiga, parodi sering digunakan sebagai alat pemberian kritik tidak hanya kepada karya asal tetapi menggunakan karya asal yang dianggap memiliki standar tinggi untuk memberikan kritik pada hal lain.18 Dengan mencermati factor-faktor tersebut di atas, sesungguhnya keberadaan parodi sangat penting artinya, oleh karenanya sudah seharusnya mendapat perlindungan hukum yang jelas, tentu saja suatu bentuk perlindungan yang tidak merugikan perlindungan hukum karya cipta asalnya.

\subsection{Perlindungan Hukum Terhadap Pemegang Hak Cipta atas Pelanggaran Hak Cipta di Bidang Sinematografi dalam Bentuk Video Parodi yang Dikomersialisasikan}

Hasil karya ciptaan memperoleh perlindungan hak cipta dengan menganut sistem perlindungan otomatis (automatically protection) artinya diperoleh oleh pencipta secara otomatis, tanpa melalui proses pencatatan terlebih dahulu pencipta secara otomatis sudah mendapat perlindungan hukum atas karya cipta nya saat karya tersebut sudah diwujudkan dalam bentuk karya cipta nyata (expression work). ${ }^{19}$ Hasil karya sinematografi dilindungi berdasarkan Pasal 40 ayat (1) huruf m UU HC. Kemudian

\footnotetext{
${ }^{17}$ Hanisa, E. I. (2014). Tinjauan Yuridis Tindakan Pengalihwujudan Atas Karya Fotografi Dalam Perspektif Hak Cipta Indonesia Dan Amerika Serikat. Kumpulan Jurnal Mahasiswa Fakultas Hukum, 1(1).

${ }_{18}$ Posner, R. A. (1992). When Is Parody Fair Use?. The Journal of Legal Studies, 21(1), 67-78.

${ }^{19}$ Dharmawan, N. K. S. (2017). Buku Ajar Hak Kekayaan Intelektual (HKI). Deepublish. Yogyakarta, h. 38-39.
} 
dalam hal karya sinematografi dibuat ulang atau ditransformasikan ke dalam suatu karya lain berupa video parodi maka hal ini kembali kepada kebijakan pencipta dan pemegang hak eksklusif atas karya sinematografi tersebut. Apabila suatu karya video parodi terebut dibuat hanya semata-mata untuk tujuan yang bukan komersil maka hal ini tidak menjadi suatu persoalan. Hal ini kemudian menjadi persoalan atas pembuatan dan pengumuman dari video parodi tersebut, pembuat video parodi memperoleh keuntungan atas hasil karya tersebut.

Berkaitan dengan penggunaan atau pemanfaatan ciptaan untuk tujuan komersial UU HC sudah mengaturnya berdasarkan Pasal 1 angka 24 UU HC. Pencipta memiliki ha katas karyanya berupa hak moral dan hak ekonomi. Berdasarkan Pasal 8 UU HC diatur bahwa hak ekonomi adalah hak eksklusif pencipta atau pemegang hak cipta untuk mendapatkan manfaat ekonomi atas ciptaan. Lebih lanjut dalam Pasal 9 Ayat (1) huruf $d$. UU HC diatur salah satunya bahwa pencipta atau pemegang hak ciptalah yang memiliki hak ekonomi untuk melakukan pengadaptasian, pengaransemenan, maupun pentransformasian atas ciptaannya. Dalam hal pihak lain ingin melaksanakan hak ekonomi untuk mengadaptasi sebagaimana diatur dalam ketentuan Pasal 9 Ayat (1), maka pihak tersebut wajib memperoleh izin pencipta atau pemegang hak cipta sebagaimana diatur melalui ketentuan Pasal 9 Ayat (2) UU HC. Meskipun tidak secara tegas disebutkan untuk karya parodi, sesungguhnya ketentuan inilah yang dapat dijadikan sebagai landasan hukum bagi pembuat parodi agar karyanya mendapat perlindungan serta tidak dianggap sebagai pelanggaran atas karya cipta asal. Sehubungan dengan hal tersebut, bagi pembuat karya cipta parodi khususnya untuk kepentingan komersial jika difahami dari ketentuan Pasal 9 Ayat (2) UU HC tampaknya wajib meminta izin dari pencipta asal suatu karya yang diadaftasi atau dijadikan dasar sebagai karya parodi. Sehubungan dengan hal itu, khusus mengenai perlindungan hak pencipta karya sinematografi yang karyanya dibuat video parodi dan dikomersialisasikan baik melalui media konvensional maupun media online seperti Youtube, perlu adanya perlindungan dan penegakan hukum yang efektif. Sebagaimana dikemukakan sebelumnya bahwa pengertian dari penggunaan secara komersial diatur dalam UU HC Pasal 1 angka 24 yang didefinisikan sebagai pemanfaatan Ciptaan dan/atau produk Hak Terkait dengan tujuan untuk memperoleh keuntungan ekonomi dari berbagai sumber atau berbayar.

Penyebarluasan seperti mengunggah karya adaptasi untuk tujuan komersial tanpa seizin pencipta atau pemegang hak cipta dapat dikategorisasikan sebagai pelanggaran hak cipta. Media online Youtube menjadi salah satu platform yang memungkinkan pengunggah video untuk memperoleh keuntungan dengan cara menyematkan pengaturan monetisasi unggahan sehingga apabila video yang diunggah dilihat oleh jumlah tertentu pengguna Youtube, maka pengunggah akan memperoleh penghasilan dari hasil unggahannya tersebut. Tindakan ini tentu dapat dikualifikasikan sebagai salah satu pengunaan secara komersial walaupun pengunggah dapat mempublikasikan ciptaannya secara gratis. Sebagaimana dijelaskan dalam Penjelasan Pasal 55 ayat (1) UU HC, dalam media elektronik informasi dan komunikasi bahwa penggunaan secara komersial mencakup penggunaan komersial secara langsung (berbayar) maupun penyediaan layanan konten gratis yang memperoleh keuntungan ekonomi dari pihak lain yang mengambil manfaat dari penggunaan Hak Cipta dan atau atau Hak Terkait. 


\section{Kesimpulan}

Parodi sebagai suatu karya kreativitas manusia baik secara internasional maupun nasional mendapat perlindungan hukum melalui rezim hak cipta. Karya video parodi yang termasuk dalam kategorisasi sinematografi yang dibuat sebagai pengalihwujudan atau karya adaptasi dari karya sinematografi asal sebelumnya, sebagai suatu ciptaan dalam konteks pengaturan Undang-Undang No. 28 Tahun 2014 (UU HC) belum memperoleh perlindungan yang jelas. Rumusan norma yang kabur pada UU HC belum dapat memberikan perlindungan yang jelas terhadap video parodi tersebut. UU HC mengatur bahwa pencipta dan pemegang hak cipta memiliki hak ekonomi untuk mengadaptasi ciptaannya, pengadaptasian oleh pihak lain untuk tujuan komersial wajib mendapat izin dari pencipta atau pemegang hak cipta. Sehubungan dengan hal tersebut, agar parodi sebagai karya adaptasi dari ciptaan asal yang dibuat untuk tujuan komersial mendapat perlindungan hukum wajib mendapat izin dari pencipta. Perlindungan terhadap ciptaan video parodi diperlukan karena suatu ciptaan video parodi walaupun dibuat berdasarkan turunan atau pengalihwujudan dari karya ciptaan lainnya, tetapi memiliki muatan-muatan baru yang merupakan hasil olah pemikiran dari pencipta video parodi. Pengaturan secara tegas tentang perlindungan hukum atas karya cipta parodi sebagai karya pengalihwujudan atau karya adaptasi beserta mekanisme perizinannya dari pencipta karya aslinya menjadi sangat penting, khususnya dalam rangka pembuatan dan pengumuman dari karya parodi termasuk video parodi sinematografi yang pembuat video parodi tersebut memperoleh keuntungan atas hasil karya tersebut.

\section{Daftar Pustaka}

\section{Buku}

Dharmawan, N. K. S. (2011). Hak Kekayaan Intelektual Dan Harmonisasi Hukum Global (Rekonstruksi Pemikiran Terhadap Perlindungan Program Komputer). Badan Penerbit Universitas Diponegoro. Semarang.

Dharmawan, N. K. S. (2017). Buku Ajar Hak Kekayaan Intelektual (HKI). Deepublish. Yogyakarta.

Marzuki, P. M., (2009). Penelitian Hukum. Kencana Prenada Media Group. Cetakan ke5, Jakarta.

Roisah, K. (2015). Konsep Hukum Hak Kekayaan Intelektual (HKI): Sejarah, Pengertian, Dan Filosofi Pengakuan HKI Dari Masa Ke Masa. Setara Press. Malang.

Soekanto, S. \& Mamuji, S. (2001). Penelitian Hukum Normatif Suatu Tinjauan Singkat. Raja Grafindo Persada. Jakarta.

\section{Jurnal}

Dewi, A. A. M. S. (2017). Perlindungan Hukum Hak Cipta Terhadap Cover Version Lagu Di Youtube. Jurnal Magister Hukum Udayana (Udayana Master Law Journal), 6(4), h. 508-510.

DOI: https://doi.org/10.24843/JMHU.2017.v06.i04.p09 
Dharmawan, N. K. S. (2017). Protecting Traditional Balinese Weaving Trough Copyright Law: Is It Appropriate?, Diponegoro Law Review, 2(1). DOI: https://doi.org/10.14710/dilrev.2.1.2017.57-84

Hanisa, E. I. (2014). Tinjauan Yuridis Tindakan Pengalihwujudan Atas Karya Fotografi Dalam Perspektif Hak Cipta Indonesia Dan Amerika Serikat. Kumpulan Jurnal Mahasiswa Fakultas Hukum, 1(1).

Posner, R. A. (1992). When Is Parody Fair Use?. The Journal of Legal Studies, 21(1), 67-78.

Supasti, N. K. (2014). Relevansi Hak Kekayaan Intelektual Dengan Hak Asasi Manusia Generasi Kedua. Jurnal Dinamika Hukum, 14(3), 518-527.

DOI: http://dx.doi.org/10.20884/1.jdh.20

Tus, D. S. A. K. (2014). Perlindungan Hukum terhadap Keaslian Cerita Rakyat. Jurnal Magister Hukum Udayana (Udayana Master Law Journal), 3(3). DOI: https://doi.org/10.24843/JMHU.2014.v03.i03.p09

\section{Peraturan Perundang-Undangan}

Undang-Undang Nomor 28 Tahun 2014 tentang Hak Cipta (Lembaran Negara Republik Indonesia Tahun 2014 Nomor 266, Tambahan Lembaran Negara Republik Indonesia Tahun 2014 Nomor 5599)

\section{Internet}

Putri, A. A. S. (2016). "Pamer" Kreativitas di Media Sosial itu Perlu, asal... . https://entertainment.kompas.com/read/2016/04/29/081628110/.Pamer.K reativitas.di.Media.Sosial.itu.Perlu.asal., diakses 28 Maret 2018.

The Encyclopedia of Britannica, https://www.britannica.com/art/parodi-literature, diakses pada tanggal 28 Maret 2018

Kamus Besar Bahasa Indonesia (KBBI) - Kamus versi online/daring (dalam jaringan), https:/ / kbbi.web.id/parodi, diakses pada tanggal 28 Maret 2018 